\title{
$[8]$
}

\section{The Rights of the Disabled}

As the I950s saw the rise of the black civil rights movement and the 1960 s the beginnings of the modern feminist movement, the 1970 s brought protest movements from the handicapped and homosexuals. ${ }^{1}$ So far, the disability rights movement has been the more successful of the two. Within its first decade, it secured passage of several federal spending laws and some fairly strong regulations for their implementation. These laws and regulations were partly the indirect result of federal court victories, but so far the success has been at least as much legislative as judicial. Constitutional arguments have been superseded by statutory ones, and judicial construction of these statutes is still in its early stages. But the Supreme Court cases that have dealt with the merits of this kind of issue could be described without exaggeration as disasters. If similar statutory cases are decided against the plaintiffs, the disabled may return to constitutional litigation.

If they do, they are not likely to get much help from the Supreme Court of the 1980 s. But that prediction does not close the issue. It is possible to construct arguments in favor of the disabled which later judges may accept. My reformulation of existing doctrine emphasized an entitlement to treatment as an equal and a linkage between equality and individual rights. Just as this reformulation provided a basis for

\footnotetext{
'I use the words "disabled" and "handicapped" interchangeably. My definition comes from the HEW regulations implementing Section 504 of the Rehabilitation Act of 1973: a "handicapped person" is a person who " $(a)$ has a physical or mental impairment that substantially limits one or more major life activities; or $(b)$ who has a record of such impairment; or $(c)$ is regarded as having such an impairment" (45 C.F.R. 85.3 I [1977]).
} 
questioning the law of age discrimination, so, I think, it can allow us to deal in new, creative ways with the rights of the handicapped. Reinterpreting the Fourteenth Amendment can also produce a foundation for the federal laws that the Court has weakened. These laws should be seen as exercises of Congress' enforcement powers under Section 5 .

To include the disabled among the subjects of this book implies that it is legitimate to consider them as a disadvantaged group, in the way that blacks or women are. An important study, written for the Carnegie Council on Children, argues that it is more useful to view the handicapped as a minority group subject to oppression than as a clientele group in need of help, as has been the traditional approach. ${ }^{2}$ In many cases handicapped people are treated like members of a minority; they are denied employment, sterilized without their consent, even come close to forfeiting their lives. The disabled are indeed subject to the kinds of invidious discrimination with which other groups are familiar.

But the problems go even deeper. The disabled often are not in a position to fight discrimination as other groups have done, for they lack the opportunities to do so. If they are ever to participate fully in society, "equal" will have to mean "more"-more money, more time, more attention.

"Had clumps of handicapped people settled in the colonies, most disabled people believe, America today would be totally accessible to the handicapped." ${ }^{3}$ Whether or not that statement is true, America is not accessible now. Public facilities are not designed for the wheelchairbound, deaf, or blind. Perhaps it need not have been that way, but beyond doubt, changing things will be costly work. If disabled people cannot move around freely, it is hard for them to vote, make demands, organize, or get jobs. So one of their major problems is lack of mobility and access.

But these are not the only necessary preconditions of full citizenship. Another is education, and historically the disabled have been short-changed here. Until the I970s, most schools could exclude any child whom they judged physically or mentally unfit. As late as 1975 , the year the Education of All Handicapped Children Act and the Developmental Disabilities Assistance and Bill of Rights Act were passed, an estimated one million handicapped children in this country got no

\footnotetext{
${ }^{2}$ John Gliedman and William Roth, The Unexpected Minority: Handicapped Children in America (New York: Harcourt Brace Jovanovich, 1980).

${ }^{3}$ Sonny Kleinfeld, The Hidden Minority: America's Handicapped (Boston: Little, Brown, 1979), p. 22.
} 
schooling at all. ${ }^{4}$ Many school systems did make provisions for educating handicapped children. They might get home instruction or attend "special" schools. There are also many private schools adapted to their needs, and some states paid all or part of the tuition. This "special education" provided some schooling for some children, but could hardly prepare them for life among the able-bodied.

Just as handicapped children have often been deprived of education, they have been denied the therapy and training they need to master such basic skills as speech and walking. For the disabled, this help is a necessary part of education. Those who became disabled as adults have fared somewhat better. Vocational rehabilitation (VR) programs have been funded by federal grants to, and sometimes matched by, the states. First established by Congress in 1920, primarily to aid disabled World War I veterans, VR has since been considerably expanded and liberalized. But the program has never met the need. Although VR has gotten thousands of people back to work, no clear statistical evidence of its overall effectiveness exists. ${ }^{5}$ The passage of the Rehabilitation Act of 1973 reflected a strong congressional agreement that VR was not enough.

The lack of mobility, education, and rehabilitation-or habilitation-has helped to exclude the disabled from full citizenship. But while improvements in these areas are necessary conditions for change, it is unlikely that even together they would be sufficient. So we come back to the question of direct discrimination. The Carnegie Council study points out that if education does bring the handicapped into full, equal participation in the work force, they will be the first disadvantaged group for which this strategy has worked. ${ }^{6}$ Even mobile, trained, and educated handicapped people have suffered discrimination, just as competent blacks and women have. So there are at least three problems here: mobility, education, and discrimination. Federal laws attack all three.

The Rehabilitation Act not only appropriated an unprecedented amount of money, but also addresses the removal of architectural barriers and provides, in its famous Section 504, that "no otherwise qualified handicapped individual ... shall, solely by reason of his handicap, be excluded from participation, be denied the benefits of, or be

${ }^{4}$ See Gene Maeroff, “Major Bill to Aid Handicapped Pupils Is Nearing Final Passage in Congress," New York Times, November 6, 1975, p. 26; Gliedman and Roth, Unexpected Minority, chap. 9.

${ }^{5}$ See Congressional Record, i i 8: 32279-316, September 26, 1972 (remarks of Senator Cranston); Gliedman and Roth, Unexpected Minority, chap. I3.

${ }^{6}$ Gliedman and Roth, Unexpected Minority, chaps. 12 and $\mathrm{I} 3$. 
subjected to discrimination under any program or activity receiving federal financial assistance." 7 Several amendments to mass transportation bills have required accessibility. The Education of All Handicapped Children Act (usually known by its number, 94-142) does what its title says it does. It establishes for all handicapped children the right to a public education appropriate to their needs, and requires that this education take place in the least segregated setting possible. ${ }^{8}$ Thus it encourages what is known as "mainstreaming": integration of disabled children with the able-bodied.

But, as important as these laws are, they came very late in our history; they of ten go unenforced; and the opposition they have met does not encourage optimism. ${ }^{9}$ For example, former president Richard Nixon vetoed the first two versions of the Rehabilitation Act as "too costly," although they had been passed by huge majorities in both houses of Congress. In October 1972, the month of his first veto, he proclaimed National Employment of the Handicapped Week, announcing that "although much has been done, there is more that must be done." If there was any inconsistency here, it escaped the president. When he did sign the bill, in September 1973, the appropriation was roughly half that of the original bill, down to about \$1.5 billion. Two years later, President Ford signed 94-I42 into law, voicing the same financial worries that had troubled Nixon. ${ }^{10}$

These concerns about cost survived those Republican administrations, as an editorial published by a liberal newspaper while Democrats controlled both presidency and Congress shows. In 1980 the Washington Post criticized a district court ruling upholding the power of the secretary of transportation, under Section 504 and several transit laws, to issue regulations making public transportation accessible to the disabled. More precisely, the editorial's concern was with Section 504 itself, which it described as "an unqualified order that should have been tempered to reflect the limits of what is possible." It continued, "Estimates of all this work run anywhere from $\$ 3$ billion to $\$ 7$

${ }^{7} 29$ U.S.C. 701 , secs. $792,794$.

${ }^{8} 20$ U.S.C., sec. $1412(5)$.

${ }^{9}$ For example, regulations to implement the Rehabilitation Act were not signed until 1977, after tumultuous national demonstrations and after a court order requiring them. See Cherry v. Mathews, 4I9 F. Supp. 922 (D.D.C. 1976); New York Times, April I, 1977, p. I 2; April 17, p. 29, April 29, p. I. In 1980, a report prepared by a coalition of children's rights groups charged that the Federal Bureau of Education for the Handicapped had virtually ignored 94-142. See Philip Taubman, "Study Says Schools Ignore the Disabled," New York Times, April 17, 1980, p. C 3 .

${ }^{10}$ New York Times, October 6, 1972, p. 39; October 28, 1972, p. I, 7; March 28, 1973, p. I; September 15, 1972, p. 58; December 3, 1974, p. 3 I. 
billion and do not take into account the physical disruption involved." 11

Of course, such concern is legitimate. What is troubling is, first, that what is "possible" appears to be a matter of what society is willing to spend, an unspecified amount that is steadily decreasing; second, that the actual regulations require that only some existing facilities be refitted, so that access will still be difficult; and, finally, that there is little recognition of the character of the interests involved. The Post put the matter in standard pluralist fashion. "To the handicapped, this is a matter of rights and dignity. ... But to Congress and all taxpayers, it is a matter of money, technology, and timing." 12 But this is far too subjective a notion of "rights and dignity." Accessibility is related to mobility, and mobility is fundamental to the exercise of individual rights. And if society is truly concerned with the dignity of all its members, this statement of countervailing interests is false and dangerous.

Of course, society is not so concerned, and is becoming, if anything, even less concerned. In the r980s, with a new conservative administration and a Senate controlled by Republicans, the federal budget has shrunk, not expanded-except, of course, for defense spending. But not all the opposition to the laws and rules is merely financial. Some of it implies that the disabled are demanding too much, expecting a place in society that is not rightfully theirs. "But the handicapped are different," intoned the last sentence of a Newsweek story, "and city officials say that limited public resources should be spent to improve the mobility of the handicapped and not try to satisfy their broader and perhaps impractical claim to equal treatment." ${ }^{13}$ The same note has been struck by some handicapped people-who, contrary to the Post's implication, are taxpayers. One letter writer to the New York Times wrote, "As disabled people, we must accept the fact that we have limitations." ${ }^{14}$

\section{Equality and Ability}

All this, of course, is backlash. By all signs, the disability rights movement is here to stay. At the same time homosexuals came out of

\footnotetext{
11 “Judge Oberdorfer's Ruling," Washington Post, February 9, 1980, p. Ar 2. The case was American Public Transit Association v. Goldschmidt, 485 F. Supp. 8 II (D.D.C. 1980). The regulations are codified in 49 C.F.R. $27.81-27.119$.

12 “Judge Oberdorfer's Ruling," p. A 2.

13 “Now, Wheelchair Rights," Newsweek, January I 5, 1979, p. 36.

${ }^{14}$ Herbert Thatcher, New York Times, August 27, 1979, p. 16.
} 
the closet, the disabled emerged from the attic, and there is no reason to expect either group to go back. ${ }^{15}$ But identifying opposition as backlash does not render it insignificant. The kinds of backlash that a social movement engenders illuminate the problems that produced the movement.

The current preoccupation with cost is part of the general opinion trend exemplified by California's Proposition 13 of 1978. Many Americans are more concerned with paring expenses than with securing a better life for their fellow citizens. The results of this attitude may be unfortunate, but the feeling is understandable, since tax burdens fall disproportionately on the white- and blue-collar workers who are a majority of the voters. The effects of the "taxpayers' revolt" may be particularly bad for the handicapped, but it is unlikely that the revolt itself has been caused by social attitudes toward disability.

When these arguments are used to oppose new programs for the disabled, however, they display a certain lack of both foresight and perspective. Handicapped people receive, and will continue to receive, federal and state money, such as supplemental security insurance. But many recipients are unable to work not because of inherent personal limitations, but because of barriers and the lack of education and training. The immediate costs of the aid programs is less than that of education, habilitation, and barrier removal, but the long-run costs may be a different story. The aggressive programs seek to get the disabled into the work force, where, as has often been pointed out, they not only will cost the government less in welfare payments but will pay taxes. Some experts estimate that the long-run cost of the new programs will be less than those of current ones. ${ }^{16}$ The failure of budgetconscious critics even to try to make these kinds of calculations suggests that both their thrift and their charity are shortsighted.

Another problem with the financial arguments is that they are not applied consistently. Mainstreaming costs less than "warehousing" (i.e., institutionalization); for example, it is cheaper to operate a group home for retarded adults than to keep them in a state hospital. But residents

${ }^{15}$ Florence B. Isbell, "Potomac Fever: How the Handicapped Won Their Rights," Civil Liberties Review 4 (November-December 1977): 61-65.

${ }^{16}$ See, e.g., a series of columns by Sylvia Porter, Washington Star, December 1976, or Frank Bowe, Rehabilitating America (New York: Harper \& Row, 1980), pp. 93-94. Bowe, who is director of the American Coalition of Citizens with Disabilities, insists that even if the highest estimated cost of barrier removal, \$20 billion over the next decade, is correct, it has to be compared to the cost, in public and private spending and lost wages, of not removing barriers, which he estimates at \$I trillion. Recipients of VR aid have, on the average, returned to the federal government in taxes four times the money spent on them (Congressional Record, I19:7104, March 8, 1973) (remarks of Rep. Hansen). 
of many communities have vehemently opposed such homes. As one case will show, these feelings have influenced legal developments. Something other than financial worry is operating here. Society is far from eager to integrate the handicapped. This feeling is illustrated by the "but they are different" arguments we have met.

That disabled people have limitations that they cannot change is true. It is not clear, however, just what it means to say that they must "accept" them; does not acceptance imply choice? But to state the issues only in this manner conceals the fact that some of these differences and limitations result not from disabilities themselves, but from an environment that exaggerates them. For instance, whatever condition puts a person in a wheelchair makes her unable to walk, and probably cannot be changed. It is a limitation she must deal with. But the absence of curb cuts on sidewalks, ramps leading into office buildings, and grab bars on toilets, which may prevent her from working, are conditions that can be changed, and therefore should not be accepted. If we fail to see the difference, we imply that physical limitations entail a kind of limited citizenship. We encourage the disabled to accept a view of themselves as marginal members of society-so marginal, indeed, that it is inappropriate for them to make political demands as most groups do.

\section{Attitudes and Doctrines}

I doubt that the attitudes I have been discussing can be blamed on court decisions, but they can be found in some of them. They surface in an opinion I have quoted more than once. Justice Brennan wrote in Frontiero, "What differentiates sex from such nonsuspect statuses as intelligence and physical disability, and aligns it with the recognized suspect criteria, is that it frequently bears no relation to ability to perform or contribute to society." ${ }^{17}$ As I suggested, this attitude makes equality dependent on being like most people, on being as competent as the norm. If this ability is lacking-if, in other words, there is a disability - then by implication, unequal treatment is legitimate. To be "different" is to forfeit the right to equality. This is an idea that pervades many of the decisions examined in this chapter, and one that already has been called into question.

This powerful connection between status and normality has a long history. It is hard to think of the Supreme Court in this connection

${ }^{17} 4$ I I U.S. 677, 686 (1973). Emphasis supplied. 
without thinking of the case of Buck v. Bell. Here eight justices upheld a Virginia court order authorizing the sterilization of "feeble-minded" Carrie Buck, whose mother and daughter were alleged to be likewise afflicted. The following passage from the opinion for the Court has often been quoted:

\begin{abstract}
We have seen more than once that the public welfare may call upon the best citizens for their lives. It would be strange if it could not call upon those who already sap the strength of the State for lesser sacrifices, often not felt to be such by those concerned, in order to prevent our being swamped with incompetence. It is better for all the world, if instead of waiting to execute degenerate offspring for crime, or to let them starve for their imbecility, society can prevent those who are manifestly unfit from continuing their kind. The principle that sustains compulsory vaccination is broad enough to cover cutting the fallopian tubes. Three generations of imbeciles are enough. ${ }^{18}$
\end{abstract}

Few disinterested commentators have had much praise for this reasoning. C. Herman Pritchett put it this way: "Seldom has so much questionable doctrine been compressed into five sentences of a Supreme Court opinion." "19 Walter Berns dealt with the penultimate sentence by remarking: "It is a broad principle indeed that sustains a needle's prick in the arm and an abdominal incision, if only in terms of the equipment used. It becomes something else again in terms of the results obtained: no smallpox in one case and no children in the other." 20

The facts were as shaky as the law. Berns's article exposed the very dubious, and long since discredited, theories of "eugenics" behind the drive for sterilization of the "unfit" in the I920s and I930s. Newspaper reports in early 1980 revealed the results in at least one state of official action on the basis of those theories. They reported that Carrie Buck and her sister, Doris, were among more than 7,500 inmates of Virginia institutions who were sterilized over a forty-eight-year period in a campaign to eliminate "social misfits." And there is considerable doubt whether Carrie or any member of her family was in fact "feebleminded" or mentally subnormal at all. ${ }^{21}$

What inspired the Court to make such errors? The quoted passage

${ }^{18} 274$ U.S. 200,207 (1927).

${ }^{19}$ The American Constitution, $3 \mathrm{~d}$ ed. (New York: McGraw-Hill, I977), p. 538.

20 “Buck v. Bell: Due Process of Law?” Western Political Quarterly 6 (1953):764.

${ }^{21}$ See, e.g., Sandra G. Boardman and Glenn Frankel, "Over 7500 Sterilized in Virginia," Washington Post, February 23, I980, pp. A1, A20; Robert L. Burgdorf and Marcia Pearce Burgdorf, "The Wicked Witch Is Almost Dead: Buck v. Bell and the Sterilization of Handicapped Persons," Temple Law Quarterly 50 (1977):955-1034. 


\section{Equality under the Constitution}

gives some hints, and reveals another, and largely ignored, defect in the opinion. The juxtaposition of the best citizens and the weakest, of the normal and the imbeciles, of society and degenerate offspring, suggests a mentality that consigns "those people" to a marginal position in that society. There is a group of people whose rights do not much matter, because they only sap the state, and anyway, they hardly notice what is being done to them. Society may let them starve, punish them, or sterilize them; there is no notion that they are part of that society or that the best citizens have any duty to them.

This bigotry is comparable to the racism of Plessy v. Ferguson or the sexism of Justice Bradley's opinion in Bradwell v. Illinois.22 It seems, but only seems, anachronistic to us now. It is not clear that anything has changed much. I mentioned Phillip Becker's case in Chapter 7, but because of his handicap, it belongs here, too, even with its happy ending. The boy's doctors testified that surgery could correct his heart defect, a common one for victims of Down's syndrome, and give him "a significant expansion of his life span." Without surgery, Phillip "will suffer a progressive loss of energy and vitality until he is forced to lead a bed-to-chair existence ... [ [and] may live at the outset 20 more years." 23

Phillip's parents refused to permit the surgery. The California courts stressed the fact that surgery did have risks, but the publicity about the case has revealed that the Beckers have other reasons for their decision. They have argued that, if allowed to live, Phillip might "burden" his two brothers, that he would be better off dying than surviving, "neglected," in an institution, and "that his life is inherently not worth living." But Phillip had made good progress in his training program, and would probably be able to work and live in a supervised setting as an adult. ${ }^{24}$

The state appeals court treated this case much as its New York counterpart had dealt with Hofbauer..$^{25}$ The judge emphasized parental autonomy and cited such "family rights" cases as Pierce, Meyer, and Yoder. "The rule is clear that the power of the appellate court begins and ends with a determination as to whether there is any substantial evidence, contradicted or uncontradicted, which will support the conclusion reached by the trier of fact." ${ }^{26}$ Since there was medical testimony that surgery carried the risk of death, this standard was

${ }^{22}$ I 63 U.S. 537 (1 896); 83 U.S. I 30, 140-42 (1872).

${ }^{23}$ In re Phillip B., App., I 56 Cal. Rptr. 48, 50 (Ct. App. Ist D. 1979); New York Times, August 9, I98I, p. 2 I.

${ }^{24}$ George F. Will, “The Case of Phillip Becker," Newsweek, April I 4, I980, p. I 2.

${ }^{25}$ Matter of Hofbauer, 393 N.E. 2 d 1009 (N.Y. Ct.App., 1979).

${ }^{26}$ I 56 Cal. Rptr. 48, 5 I. 
met. The opinion ignored the evidence that the parents' decision was based on the fact that Phillip is retarded, and that the result of this decision was to suggest that a retarded child does not have the same rights to treatment, and indeed to life, as his normal counterpart. The Supreme Court's refusal to hear the case is silent evidence that it may not have come far enough from Buck v. Bell. That case reasoned from no smallpox to no children; Bothman v. Warren B. progresses to no life.

Although a lawyer interviewed on 60 Minutes described Bothman as "an equal-protection case," it was brought and decided as a custody case. What happens, though, if we do consider disability rights issues in a constitutional context? If the handicapped get different treatment, are they being denied their constitutional rights? The answer to that question seems to depend on what they are not getting. If it is education, Rodriguez implies a negative answer; as for accessibility, the earliest cases reach a similar conclusion. ${ }^{27}$ Neither of these results is beyond challenge, but they do reflect current doctrine.

Is disability a suspect classification? That depends on which version of suspect classification one adopts. Marcia Pearce Burgdorf and Robert Burgdorf have relied on the "discrete and insular minorities" component of Carolene Products and the "saddled with such disabilities" text of Rodriguez to argue the affirmative, and that argument is tenable. ${ }^{28}$ But the Frontiero version weighs against it. It is possible to quote it selectively. The Burgdorfs do so in exactly the same way as does a 1976 North Dakota case: "We are confident that the Court would have held that G. H.'s terrible handicaps are just the sort of 'immutable characteristic determined solely by the accident of birth' to which the 'inherently suspect' classification would be applied." 29

This is law-office history with a vengeance. It cuts Frontiero in half. Two scholars, one a lawyer and one a doctor, do try to fit the retarded, at least, into the second half. This classification, they insist, "'frequently bears no relation to the ability to perform or contribute to society' [but] is a stereotyped self-fulfilling prophecy." ${ }^{30}$ This argument is not much better, however, for it too easily substitutes the label

${ }^{27}$ Snowden v. Birmingham-Jefferson County Transit Authority, 407 F. Supp. 394 (N.D. Ala. I975); United Handicapped Federation v. André, 409 F. Supp. I 297 (D. Minn. 1976).

28 "A History of Unequal Treatment: The Qualifications of Handicapped Persons as a 'Suspect Class' under the Equal Protection Clause," Santa Clara Lawyer I5 (1975):906.

${ }^{29}$ In Interest of G. H., 218 N.W. 2d 44I, 447 (Sup.Ct. N.D.); Burgdorf and Burgdorf, "History of Unequal Treatment," p. 905.

${ }^{30}$ Bruce G. Mason and Frank J. Merolascino, "The Right to Treatment for Mentally Retarded Citizens: An Evolving Legal and Scientific Interface," Creighton Law Review Io (October 1976): 162. 


\section{Equality under the Constitution}

for the condition. And the condition of being retarded is just not comparable to the condition of being a woman. The cases themselves, winding through intricate constitutional and statutory questions, sometimes reach these issues and sometimes evade them.

\section{Education and Treatment}

I have suggested that a notion of the handicapped as marginal persons has led society to be stingy about providing them with therapy, habilitation, and education. But Buck v. Bell reveals another problem, just as serious, which is polar to the first and which is to the fore in the education cases. To say that we regard the handicapped as inferior assumes a real handicap. But such words as "disabled" and "handicapped" do more than refer to conditions. They are also labels, which help assign people to social statuses. A major problem with labels is that they can be wrongly applied. This problem is especially severe for children, because they so often run up against government power in the person of school authorities.

Some of the cases that I have to skip over involve the assignment of schoolchildren to "emotionally disturbed" or "educable mentally retarded" classes, often on the basis of IQ tests and over the protests of their parents; most of the children so assigned were black, and there is ground for suspicion that their "handicaps" existed mainly on paper and in their teachers' judgments. ${ }^{31}$ One case deals with a school's effort to assign a child to a "special" school because of a less than catastrophic defect. ${ }^{32}$ The dangers increase when the label is some fuzzy concept like "minimal brain dysfunction" or "learning disability." ${ }^{33}$ Children are vulnerable to "help" and "therapy"-that is, coercionthey do not need. "Mainstreaming" reduces these dangers by making it harder to exclude children from regular classes, but 94-I42 does permit flexibility here. Worse, to quote a popular maxim of the child experts, "labeling is disabling"; it can cause or aggravate the very problems we are trying to relieve.

But this concern cannot monopolize our thinking either. Labeling is disabling, yes, but so are blindness, paraplegia, and Down's syndrome. The situation is not perfectly parallel to Parham or Gault,

${ }^{31}$ See Larry P. v. Riles, 343 F. Supp. 1306 (N.D. Cal. 1972); 502 F. 2 d 963 (9th Circ. 1974); Lora v. Board of Education, 456 F. Supp. 12 I I (E.D.N.Y., 1978), 623 F. 2 d 248 (2d Circ. 1980).

${ }^{32}$ Hairston v. Drosick, 423 F. Supp. I80 (S.D. W.Va. 1976).

${ }^{33}$ See Divoky and Schrag, Myth of the Hyperactive Child. 
where children were labeled "mentally ill" or "delinquent" without good evidence to support the diagnoses. There are many disabilities that treatment can help, and that are catastrophic without it. The blind or retarded person cannot become self-sufficient without professional help, and, for children, that help may feel very much like coercion. Some labeling is a precondition for receiving this kind of help. However attractive "radical nonintervention" may be as an approach to delinquency, it will not do as an approach to disability. ${ }^{34}$

Both polarities were evident in the next two cases. Decided three months apart in 1972, they were to the disability rights movement what Brown was to the fight for racial equality. They were Pennsylvania Association for Retarded Children (PARC) v. Pennsylvania and Mills v. Board of Education. ${ }^{35}$ Both involved suits brought not on behalf of children assigned to special classes or subjected to unwanted "help," but for children excluded from public schools.

Pennsylvania exempted from its compulsory education law, and relieved the state Board of Education of all responsibility for, any child who was classified by a school psychologist as uneducable and untrainable. ${ }^{36}$ There were some free public programs for the retarded, and some children attended private schools at state expense, but these programs could not accommodate all children removed from public school. There was evidence of "crass and summary treatment" of the children; in some cases, the parents were not even informed of the decision. During the litigation, however, an interim stipulation provided that any child and parent had a right to hearing, notice, counsel, and cross-examination of witnesses before exclusion. ${ }^{37}$

PARC brought this action on behalf of all retarded children between the ages of six and twenty-one who were excluded from the state's public schools. "Plaintiffs do not challenge the separation of special classes for retarded children from regular classes or the proper assignment of retarded children to special classes. Rather plaintiffs question whether the state, having undertaken to provide public education to some children (perhaps all children) may deny it to plaintiffs entirely." The parties had reached a court-approved consent agreement that obliged the state to educate each child in an appropriate setting. ${ }^{38}$

The District of Columbia gave officials even more power to exclude children than Pennsylvania did. The city's code exempted any child

\footnotetext{
${ }^{34}$ The title of a book by Edwin M. Schur. See Chapter 7, n. 75 .

${ }^{35} 343$ F. Supp. 279 (E.D. Pa. 1972); 348 F. Supp. 866 (D.D.C. 1972).

${ }_{36}^{36}$ Purd. Stat. Sec. 13-1330, 13-1 375.

${ }^{37} 343$ F. Supp. 279, 296, 293, 284-85.

${ }^{38}$ Ibid., pp. 297, 285.
} 


\section{Equality under the Constitution}

who was "mentally or physically unfit." ${ }^{39}$ As in Pennsylvania, there was a special education program, but it was inadequate for all eligible children; the school system estimated that more than 12,000 handicapped children got no public education at all. The seven child plaintiffs in Mills had been threatened with exclusion because they were allegedly "emotionally disturbed," "behavior problems," "mentally retarded," or "hyperactive." ${ }^{40}$ Perhaps unremarkably for Washington, all seven were black. The suit was brought, however, on behalf of all children in the District, of whatever race, excluded from free public education.

Chapter 7 showed that the exclusion of children from school raises grave questions of procedural due process. But there are substantive problems, too, and here they will not go away so easily as they were made to in Lopez. Both the Pennsylvania and the District regulations indicate that the potential existed for both problems I have identified, mislabeling and nonhelping. Especially in Washington, the schoolchild was vulnerable to a diagnosis that might or might not be correct. If a school professional labeled her "unfit," she was out (or, rarely, forced into special education classes), whether or not she actually had a disabling condition. This situation is bad enough, but suppose the child was indeed retarded. Unless the parents could afford private schooling, such a child would not get the help she needed.

The three-judge courts were sensitive to both problems. They ruled the laws unconstitutional on both procedural and substantive grounds. Both Judge Thomas Masterson in Philadelphia and Judge Joseph Waddy in Washington emphasized the lack of a hearing (although Pennsylvania had agreed to start holding one). Each opinion forbade special placement without notice, hearing, counsel, or other procedural safeguards, and each went further, into substantive due process and equal protection. ${ }^{41}$ The panels ruled that the respective governments had a constitutional duty to provide all children with an adequate education.

Masterson was concerned about "the stigma which our society unfortunately attaches to the label of mental retardation." He cited Wisconsin v. Constantineau, ${ }^{42}$ in which the Supreme Court had invalidated a law that allowed police to forbid the sale of liquor to anyone classified as an excessive drinker and thus established "the necessity

${ }^{39}$ D.C. Code Sec. $3 \mathrm{I}-203$, quoted at 348 F. Supp. 866,874 .

40348 F. Supp. 866, 868-70.

${ }^{41}$ Any reader who is puzzled about how equal protection applies to the District is referred to Bolling v. Sharpe, 347 U.S. 497 (1954).

${ }^{42} 400$ U.S. 433 (I971). 
of a due process hearing before the state stigmatizes any citizen." But Masterson went beyond notice and hearing. He attacked the implied identification of "retarded" with "uneducable and untrainable," declaring: "Without exception, expert opinion indicates that all mentally retarded persons are capable of benefitting from a program of education and training." He concluded: "We are satisfied that the evidence raises serious doubts (and hence a colorable claim) as to the existence of a rational basis for such exclusions." ${ }^{43}$ Therefore, the law ran afoul of equal-protection guarantees.

Judge Waddy was disturbed less by any lack of rationality than by the denial of what he viewed as a fundamental right. (This was a year before the Supreme Court ruled in Rodriguez that education was not to be so ranked.) Waddy cited Brown I, as cases on the education of handicapped children often do: "In these days, it is doubtful that any child may reasonably be expected to succeed in life if he is denied the opportunity of an education. Such an opportunity, where the State has undertaken to provide it, is a right which must be made available to all on equal terms." Waddy also relied on Hobson v. Hansen, where Judge J. Skelly Wright had ruled that the District's ability-grouping system violated the due-process clause. ${ }^{44}$ Mills ended with seven pages of requirements for publicizing the ruling, notifying the children and parents involved, hearings, and procedures.

The Mills and PARC decisions suggest comparisons other than Brown and Hobson. They can be interpreted as doing for, or to, school systems what Wyatt v. Stickney did for mental hospitals and James v. Wallace for prisons. ${ }^{45}$ Of course, Mills and PARC could no more enforce themselves than any of those decisions could. But they could and did start events in motion. Indeed, they may turn out to be similar to Brown in their ultimate effects. Within a few years, there was important new legislation; ultimately it may have profound and far-reaching effects on social attitudes and behavior.

The Education of All Handicapped Children Act and some state laws have established rights that these two cases grounded in the Constitution, along with some glosses such as "mainstreaming." Therefore, these claims need no longer depend on constitutional arguments. But emphasis on these early rulings is no wasted exercise. Constitutional grounds may ultimately be firmer than laws that can be changed

${ }^{43}$ PARC v. Pennsylvania, 343 F. Supp. 279, 295-97.

${ }^{44}$ Mills v. Board of Education, 348 F. Supp. 866, 875, quoting 347 U.S. 483,493 (1954) (emphasis supplied by Judge Waddy); 269 F. Supp. 40I (D.D.C. 1967).

${ }_{45} 325$ F. Supp. 78I (M.D. Ala. 197I); 334 F. Supp. I34 and 387 (1972); 406 F. Supp. 3 I 8 (M.D. Ala. 1976). 


\section{Equality under the Constitution}

or appropriations that can be cut. Now that suits under the 1973 and I975 acts are moving through the courts, judges tend to avoid constitutional questions in favor of statutory ones. But many cases raise both kinds of issues.

Mills and PARC avoid certain lines of reasoning that might have been traps. Unlike some writers I quoted earlier, they do not do much with suspect classification. All that is "suspect" in PARC is careless labeling, and Mills does not get into this aspect of the problem at all. Taken together, the two cases establish, first, that exclusion is invalid when no rational basis for it exists, and second, that education must be provided to all on an equal basis. These are two notions with long pedigrees, especially the first.

Rodriguez, with its ruling that there is no constitutional right to education, may appear to call the second conclusion into question, but the decisions have not been consistent. (Indeed, Rodriguez may provide some help here, since it did allow unequal expenditures, and education may be more costly for the handicapped than for normal children.) A 1976 case did rely on Rodriguez to justify exclusion of retarded children, and three years later a California court suggested that Rodriguez had weakened PARC and Mills, but had no effect on 94-I 42. ${ }^{46}$ But other decisions have pointed out that Rodriguez did not deny that states had a duty to provide all children with an adequate education, nor did it sanction exclusion. ${ }^{47}$

To the extent that Mills contradicts Rodriguez, I think Judge Waddy has the better argument. The dissenters in Rodriguez did an excellent job of arguing that education is fundamental to the exercise of such explicitly granted rights as voting and freedom of expression. ${ }^{48}$ But losing the fundamental-right skirmish does not mean losing the case, so these rulings can stand even after Rodriguez. For once, traditional due-process and equal-protection analysis work rather well-in those particular cases.

But what happens in subsequent cases? What does an adequate education consist of? If blanket exclusion of the "retarded" is invalid, can a particular child be excluded after an expert determination? Who decides, and how, where to place a child? Is mainstreaming desirable always, sometimes, or never? If ever, when?

${ }^{46}$ Cuyahoga County Association for Retarded Children and Adults v. Essex, 4 I I F. Supp. 46, 50 (N.D. Ohio 1976); Boxall v. Sequoia Union High School District, 464 F. Supp. I 104, I 107-8 (N.D. Cal. I 979).

${ }^{47}$ Fialkowski v. Shapp, 405 F. Supp. 946, 958 (E.D. Pa. 1975); Kruse v. Campbell, 43 I F. Supp. I 80 (E.D. Va. I 977), vacated and remanded sub. nom. Campbell v. Kruse, 434 U.S. 808 (1977).

${ }_{48}^{4}$ I I U.S. I, 62-63 (Brennan dissenting), 7 I-72, 99-IO2 (Marshall dissenting). 
Although the new laws have dealt with these questions, judgesoften the same ones-are still tackling these problems. Laws that create rights usually increase rather than reduce the judicial workload, and $94-142$ has been no exception. Since some of the cases were begun before the law went into effect, constitutional questions still appear. And since the law is still young, there is not much definitive judicial interpretation.

The cases present a variety of factual situations and legal issues. I have chosen to examine some cases that focus on individual rather than collective applications. The cases do not easily sort themselves into patterns, but I divide them rather loosely into two groups. The first group involves what I have been calling nonhelping: exclusion or inadequate schooling. The second group involves mislabeling: assigning, tracking, even institutionalizing on shaky evidence of the need. One case, arguably, involves both.

Early in 1976 , two district court cases reached conclusions that provide a revealing contrast. Eighteen-year-old Diana Taylor, legally blind and multiply handicapped, had entered the Maryland School for the Blind, a residential facility, in 1973. After two years, the school decided to terminate her enrollment, alleging that "despite intense work" she was not benefiting. Some staff members testified that she had actually regressed from a two-year-old level to that of an eighteen-monthold. After a hearing before the school's admissions committee, at which Diana and her parents were represented by counsel, the committee upheld the recommendation. Diana was transferred to a public custodial institution. Her parents sued, but the court upheld the school.

Judge Joseph Young found that "a forced transfer from an educational institution for the handicapped to a custodial one should be governed by the due process clause," but that the hearing satisfied these guarantees. The fact that it was held by the school's own committee did not taint it, since the Taylors had counsel and the right to present and confront witnesses. This case was distinguishable from Mills and PARC because proper cause for dismissal existed. The judge reviewed the evidence, using the "rational basis" standard. Though there were disagreements, "no matter which standard of review this Court chooses to adopt, it cannot say that the finding of the school that Diana has made no real progress ... is incorrect." ${ }^{49}$

Taylor suggests that, once procedural rules are observed, substantive barriers to exclusion may fall. In the face of any evidence to support the decision that the child was not educable, the court would

${ }^{49}$ Taylor v. Maryland School for the Blind, 409 F. Supp. 148, 15 I-54 (D. Md. 1976). 


\section{Equality under the Constitution}

uphold the school. This begins to sound like the school cases examined in the last chapter. There, however firm the demands for a hearing, the courts refrained from discussing the offenses the children were being punished for. If the judges were troubled that a child was suspended for disrespect or paddled for dawdling, they kept their qualms to themselves.

Generalizing from some of the views honored in those cases, it is plausible to assume that some of the judges were deferring to the supposed superior wisdom of the school officials. Judge Young seems to be doing the same. But it is harder to condemn his deference to pedagogical authority. We might expect judges to have a common-sense understanding of discipline, but-given the fact that they grew up in the days before mainstreaming-is it reasonable to expect them to know much about multiply handicapped children? Why should it occur to Judge Young that from some perspectives two years might seem too soon to give up? The PARC consent agreement gathered much general expert knowledge about retardation, but in a specific case it is difficult to argue with experts who know the child.

Taylor is equally disturbing for another reason. It suggests that the educational system has to be taken as a given. Rather than the state having an obligation to design a system from which all children can benefit, the children have to fit into the system as it exists. ${ }^{50}$

It is useful to contrast Taylor with Hairston v. Drosick. Hairston touches both poles of mislabeling and nonhelping. It began in September 1975, with a telephone call to the mother of six-year-old Trina Hairston from her prospective first-grade teacher.

Trina had been born with spina bifida. She limped and her bowel control was imperfect, but she was physically and mentally competent to attend regular school. The year before, Gary Grade School in McDowell County, West Virginia, had at first refused to let her into kindergarten, but had admitted her for the second half of the school year. Just before the $1975-76$ academic year started, the teacher whose class Trina was to enter telephoned Sheila Hairston to tell her that her daughter was "not wanted" there and would not be admitted.

"Upon going to the school after extensive discussion," Mrs. Hairston was told by school authorities that Trina could attend only if her mother came to class. Finally the school superintendent gave the Hairstons three choices. Trina could attend school with her mother; she could get homebound instruction; or she could go to a school for

\footnotetext{
${ }^{50} \mathrm{~A}$ similar decision was rendered in Cuyahoga County Association v. Essex, cited in n. 46.
} 
handicapped children. No hearing was held, nor was Trina examined by a school physician. None of these choices was satisfactory to the Hairstons. They charged that the school's actions violated both Section 504 of the 1973 act and the due-process clause of the Fourteenth Amendment.

The district judge agreed. He found Trina's exclusion "without a bona fide educational reason" inconsistent with the statute and the denial of a hearing in violation of due process. He ruled that the Hairstons must have an opportunity to get medical evaluations and other evidence before a hearing was held. In the meantime, the school must admit Trina, who had already lost half a year of first grade.

The opinion found, as matters of fact, that "a great number of spina bifida children," most of them in worse condition than Trina, attended public schools in West Virginia; that Trina would get a grossly inferior education at the special school; and that it was an "educational fact that the maximum benefits to a child are received by placement in as normal environment as possible" and "that handicapped children should be excluded from the regular classroom only as a last resort." ${ }^{51}$ The conclusions of law were brief, without rhetoric. Perhaps Hairston is a "horrible example," for the attitudes of teachers and officials were extreme. We can welcome the decision, however, for cracking down on this sort of placement-while we must wonder how many children have been ghettoized into special schools, or entirely excluded, on grounds as specious as this. In Taylor, it was evident that the schools were dealing with real and serious problems. No one can dispute that educating a blind retarded child is a difficult task. But Hairston reads suspiciously as if the problems were of the school's own making. A limp does not interfere with learning to read and write, the main tasks of the first grade, but losing half a school year may. And after all, at that age "accidents" are a common classroom occurrence. Hairston may be a horrible example of pedagogical bigotry, but it is a good example of the ways official action can worsen the consequences of a disability. This case fits neatly into Title $\mathrm{V}$ of the Rehabilitation Act and the procedural sections of Mills and PARC. It does leave open one question, however: If a due-process hearing had been held, would a substantive constitutional issue exist?

The question is disturbing, for, as Taylor shows, a hearing can be biased in favor of the experts. Equality demands substantive as well as procedural guarantees. Disabled children, like all children, need an education; segregation into "special" schools is no more an equal edu-

${ }_{41}^{51}$ F. Supp. I 80, I82-84 (S.D. W.Va. 1976). 


\section{Equality under the Constitution}

cation for them than it is for black children. What Chief Justice Warren said in Brown is surely true for such children as Trina. Segregation would have generated ineluctable feelings of inferiority and affected her ability to take full part in her community. The new laws are welcome for their efforts to prevent such segregation, but it remains to be seen how effectively they will be enforced.

\section{Rights of Mobility}

I have argued that education and training are necessary but not sufficient conditions for full equality for disabled people. An accessible environment is another necessity, and the issues involved here are equally complex and traditional doctrine just as restrictive. The Supreme Court has not dealt yet with this issue. The Court's views may not matter much, however, as barrier removal is not among the priorities of the Reagan administration. ${ }^{52}$

The ramps, curb cuts, and Braille signs that have become familiar sights since the r970s are testimony to a long history of architectural barriers. Our physical environment has long been inimical to the disabled. Sidewalks, buses, and buildings have been inaccessible to people in wheelchairs, marginally accessible to people using canes and crutches, and ill adapted to the blind and deaf. Perhaps we need not have built curbs, buses with high steps, and multistory buildings with stairs and narrow elevators. But they were built this way, and they have helped to keep the disabled from full participation in American life. This segregation, for such it is, has perpetuated itself, for "the physically handicapped have long been invisible to the majoritarian forces of selfgovernance." ${ }^{33}$ The disabled have thus been in no position to demand the changes that would integrate them.

What forms could such a demand take? How is it possible to speak of a right to an accessible environment? Courts have recognized a constitutional right to travel and have struck down direct and indirect limitations on it, but this right has been held not to include rights of accessibility. ${ }^{54}$ Several federal laws and regulations, however, do es-

\footnotetext{
${ }^{52}$ The Architectural and Transportation Barriers Compliance Board's regulations, which mandate that all federal buildings be made accessible, have been a chief target of VicePresident George Bush's Regulatory Review Task Force (Felicity Barringer, "U.S. Board Vote May Spell End to Handicap Regulations," Albany [N.Y.] Times-Union, July I I, I98I, pp. I, 5).

${ }^{53}$ Atlantis v. Adams, 453 F. Supp. 825, 829 (D. Colo. 1978).

${ }^{54}$ Crandall v. Nevada, 6 Wall. 35 (1868); Edwards v. California, 314 U.S. I60 (I94I); Shapiro v. Thompson, 394 U.S. 6 I8 (1968); cases cited in n. 27.
} 
tablish some limited rights. The first set of regulations implementing Section 504, issued more than three years after the law was passed, stipulated that recipients of federal funds must provide handicapped people with services "as effective as those provided to others," and that, with few exceptions, all new facilities must be fully accessible. The first Supreme Court ruling on 504 threatens this interpretation. ${ }^{55}$

Snowden v. Birmingham-Jefferson County Transit Authority and United Handicapped Federation v. André brought both statutory and constitutional claims against the Birmingham and Minneapolis transit system. Both courts quickly dismissed the constitutional claims. The plaintiffs had asserted that they were denied equal protection, citing Mills, PARC, and the right-to-travel cases. Snowden was curt: "Plaintiff cannot credibly maintain that access to public transportation facilities is a 'fundamental right' on a parity with the right to an education at public expense which must be made available to all on equal terms.... 'The Constitution as a continuously operative charter of government' does not demand the impossible or the impracticable." 56 André agreed: "The alleged violations of constitutional rights are not based on allegations that defendants prohibit plaintiffs from riding MTC vehicles, but rather that defendants have failed to specifically equip the buses to transport the wheelchair handicapped. The Court is not convinced that the Constitution, absent a statutory mandate, places an affirmative duty on the defendants to provide special facilities for a special class of people." 57

This choice of words is striking. What connections might there be between "special class" and "suspect class"? The disabled, as I have argued, do fit one definition of suspect classification, the one that seems better attuned to constitutional intent. And inaccessible transportation saddles handicapped people with disabilities even greater than the ones they already have. The environment militates against schooling, voting, political action, and other rights both fundamental and derivative. Inaccessibility helps to create a disadvantaged group just as powerfully as compulsory retirement does for the elderly.

The difficulty with this argument is that it is not the law that makes facilities inaccessible. Such direct discrimination has existed; for example, most airlines once refused to allow the mobility-impaired to travel alone. The Snowden and André opinions are quite correct in

\footnotetext{
${ }^{55} 45$ C.F.R. 84.4(b) (1977), 85.58 (1978); Southeastern Community College v. Davis, 99 S.Ct. 236I (1979).

${ }^{56} 407$ F. Supp. 394, 398 (M.D. Ala. 1975). The interior quotation is from Yakus v. United States, 32 I U.S. 414, 424 (1943).

${ }^{57} 409$ F. Supp. I 297, 130 (D. Minn. 1 976).
} 
their assertions that no comparable rules exist in these cases. Nor is this situation quite like a facially neutral policy that in fact results in discrimination, such as employment requirements that somehow keep blacks out of all but the lowest-paying jobs, ${ }^{58}$ or Anatole France's famous example, the law that keeps both rich and poor from sleeping under bridges. Snowden puts it this way: "Such discrimination as may in fact exist results from technological and operational difficulties in designing, producing and operating the kinds of special vehicles needed to allow plaintiffs ... to utilize BJCTA's bus system with safety and convenience for themselves and others." 59

But look closely at those difficulties. One that the judge does not mention is that Jane Snowden must use a wheelchair. Medical science cannot get all patients out of wheelchairs and onto their feet. Nor do we know how to build wheelchairs that can climb stairs. All the government can do about either of those limitations is to fund research to find ways of changing them, with no guarantee of eventual success. But the third set of technological difficulties has to do with the bus itself. The technology required to lift wheelchairs into buses has been available for some time; either ramps or lifts are needed. Minneapolis' vans are evidence of this knowledge. Transbus, the result of DOTfunded research, has been a very late effort to use this technology. It will not be available until 1985 at the earliest, and no fully accessible bus now exists, but the transit systems we have now could have been made more accessible than they now are.

As a society, we have chosen not to build buses that way, just as we chose stairs instead of ramps, curbs without cuts, and toilets without grab bars. Designers of public facilities do take human anatomy into account in their work-the anatomy of the able-bodied. Where technology is deficient, as it has been with buses, innovation has not been a high priority. So, in a sense, it is the law-the appropriations not made, the grants not awarded, the limitations not considered-that has made the facilities inaccessible. If the equal-protection guarantees are to be interpreted as I have argued, with an emphasis on empowering and enabling citizens and respecting their dignity, why not a constitutional right to accessibility?

\section{On Not Hiring the Handicapped}

Hire the Handicapped Week has been an annual event since the late I940S. Just as predictable but more frequent have been the public-

\footnotetext{
${ }^{58}$ See Griggs v. Duke Power Co., 40I U.S. 424 (I97I).
}

${ }^{59} 407$ F. Supp. 394, 398. 
service advertisements aired on late-night television, which typically show an exemplary handicapped worker as the adult equivalent of a poster child in a fund-raising campaign. But there is little evidence that either the proclamations or the commercials have encouraged employers to hire handicapped workers.

The earlier sections of this chapter suggest two partial explanations for this failure; first, that many handicapped people have been deprived of the schooling needed to fit them for work; and second, that environmental barriers often immobilize them. But these are not the only reasons. After all, many disabled people have gotten an education, and-whatever contrary impression the last section may have given-most are not in wheelchairs and can cope with their environment. There is a third problem: outright discrimination, often based on prejudice, ignorance, and fear. ${ }^{60}$ Here again exclusion has perpetuated itself. Not only has it prevented the handicapped from making claims, but it has prevented the able-bodied from learning about handicapped people. Thus the ignorant remain ignorant.

When the Coalition of Citizens with Disabilities asked to join the Leadership Conference on Civil Rights, a conference official demurred. Although surely he should have known better, he asked, "Can't what you want be accomplished by a little public education?" The coalition official replied, "A permanent injunction against discrimination is about the most effective educational tool I know of." ${ }^{61}$ It is arguable, and has been argued, that either the Constitution, Section 504 , or both provide the basis for such an order.

The first constitutional case was settled out of court. It was brought by Judith Heumann, who has become a prominent disability rights activist. A polio victim, Heumann has used a wheelchair most of her life. In April 1970 she was twenty-two years old and an honor graduate of Long Island University. She applied to the New York City Board of Education for a teacher's license.

The board turned her down, arguing that she would be unable to protect herself or her students in emergencies. Several blind teachers and persons using canes or crutches, however, had recently been licensed. Heumann filed suit in federal district court. In her ultimately successful struggle, she soon gained an ally in the New York Times. An editorial called the board's decision "heartless and thoughtless nonsense." It suggested that handicapped persons, often more admi-

\footnotetext{
${ }^{60}$ See Frank Bowe, Handicapping America (New York: Harper \& Row, 1978), chap. 6; Gliedman and Roth, Unexpected Minority, chaps. 12 and 13.

${ }^{61}$ Isbell, "Potomac Fever," p. 64.
} 


\section{Equality under the Constitution}

rable than "acclaimed hero-athletes," could provide "a thoughtprovoking example" for their students. ${ }^{62}$

That, of course, is the traditional rhetoric of disability. It surfaces mainly in situations such as this; discussions of education and accessibility do not fall back on it. Many disabled people are suspicious of this kind of talk, perhaps because it has long been a staple ingredient of American life, parallel to the long history of bigotry and neglect. It has been easier to praise the disabled than to include them. This sort of editoralizing is not a good basis for a decision; perhaps, rather than examples, handicapped teachers would prefer to be regarded simply as human beings. Heumann was suing for employment, not idealization. But for once this rhetoric was joined to a practical recommendation.

The suit was settled when the board reversed itself and awarded Heumann a license. The next year, the state's education law was amended to prohibit discrimination against physically handicapped applicants for teaching positions. ${ }^{63}$ The issues were not resolved in court. If they had been, the rational-basis test by itself might have demanded a decision for Heumann, since the evidence showed that others who might be equally unfit in emergencies had been hired.

A judicial determination had to wait until 1976 , when Judith Gurmankin sought to become one of the approximately five hundred blind public school teachers in the United States. She had done some student teaching of high school English, and had been interviewed by Philadelphia school authorities, but had not been allowed to take the necessary qualifying examinations. A regulation prohibited anyone with a "chronic or acute physical defect" from taking these tests. Gurmankin alleged that her Fourteenth Amendment rights had been violated. Since no regulations on Section 504 had yet been issued, she could not easily include it.

The evidence on her student teaching was mixed. Her students were enthusiastic about her performance, but her supervisor reported that she needed an extraordinary amount of help from teacher aides. What troubled the district judge, however, was, first, that Gurmankin's interviewers did not give her much opportunity to explain how she would do her job, and second, that the regulation created an "irrebuttable presumption" that the handicapped were incapable of teaching. "I have concluded that Ms. Gurmankin was not evaluated fairly. The grading of the oral examination was based, at least in part, on mis-

\footnotetext{
${ }^{62}$ New York Times, April I, 1970, p. 35; May 27, 1970, p. 33; June 2, 1970, p. 38.

${ }^{63}$ Ibid., June 20, I970, p. I7; May 6, 1971, p. 55.
} 
conceptions and stereotypes about the blind and on assumptions that the blind simply cannot perform while the facts indicate that blind persons can be successful teachers." ${ }^{64}$ The board could take her blindness into consideration, the judge ruled, but Gurmankin would have to be hired to give her a chance to show that she could do the job. ${ }^{65}$

Heumann's and Gurmankin's experiences suggest that if some claims involving the handicapped are assigned to the traditional lower tiers of Fourteenth Amendment adjudication, they may succeed. These two episodes, however, do not dispose of all possible constitutional issues. It is easy to imagine harder cases. Suppose New York City had consistently imposed a requirement that teachers be able to deal with emergencies; or, for that matter, that they be assigned lunchroom or corridor duties. Are these tasks properly part of a teacher's job? They have gotten to be, but does that settle the question? Suppose an applicant could not perform tasks that have come to seem an integral part of teaching, such as writing on the blackboard, or that Judith Gurmankin really did need extra help from aides. Would these be grounds for disqualification? If a priori assumptions are abandoned, what constitutes evidence of ability or disability? Must job requirements be accepted as givens, or may they-or must they-be modified to suit the disabled?

The leading Rehabilitation Act case, Southeastern Community College v. Davis, answered these questions in ways unfavorable to the disabled. ${ }^{66}$ But how would constitutional doctrine handle these issues? Davis would probably meet the requirements of Guntherian rationality scrutiny. The stereotyped assumptions and irrebuttable presumptions that pervaded Gurmankin were replaced by the tested opinions of doctors and administrators.

As for the top tier, there is no better way to reveal the difficulties inherent in both suspect-classification doctrines than to examine discrimination based on disability. The Frontiero formulation, taken in its entirety, forecloses inquiry; it depends on lack of connection between characteristic and ability, and here that connection is present by definition. But that formulation is at odds with itself. The opinion also suggests that there is something wrong with penalizing people because of something they cannot help and cannot change. If that concept ap-

${ }^{64}$ Gurmankin v. Costanzo, 4 I I F. Supp. 982, 984-8 5, 990-9I (E.D. Pa. I 976), citing Vlandis v. Kline, 4 I 2 U.S. 44I (1973); Cleveland Board of Education v. LaFleur, 4I 4 U.S. 632 (1974); 4II F. Supp. 982, 987-88.

${ }^{65}$ This decision was affirmed in Gurmankin v. Costanzo, 556 F. 2d 184 (3d Circ. 1977).

${ }^{66} 99$ S.Ct. 236 I (1979). 


\section{Equality under the Constitution}

plies to gender, which does not limit a person's ability, surely it must apply even more stringently to handicaps, which do. But the opposite is true. ${ }^{67}$

And with good reason. It may be more cruel to burden a blind person than a woman, but it is a fact, for instance, that women make competent truck drivers and blind people do not. Job discrimination against the blind may hurt them, but it is often thoroughly reasonable, even necessary. The application of Frontiero thus leads to confusion. Part of that rule refuses the disabled any protection, but another part implies that they deserve it the most. The doctrine leaves a gap here; it does not allow us to distinguish between acceptable and unacceptable types of discrimination.

Although I have a general preference for the "insular minority" formulation of the doctrine, it presents similar problems when applied to disability. It sounds good; who could be weaker, more isolated, more stigmatized than those disabled by an immutable, accidental characteristic? But that formulation would suggest that any discrimination against the disabled is unconstitutional, and again, the hypothetical case shows that this cannot be true.

We have been dealing with conceptual problems as well as legal ones. I have applied to the disabled some concepts borrowed from equal-protection litigation. But this practice is not always satisfactory, for it is hard to think about disability rights as we think about the rights of blacks and women. The barriers I have discussed have isolated so many handicapped people, and for so long, that the ablebodied majority is simply not so familiar with the disabled minority as it is with blacks and women. It is hard to know what demands the disabled would make, and in what ways, if they were as visible as other disadvantaged groups.

The legal questions are difficult, too. The deeper one gets into the law of disability, the worse the established categories seem to fit. In some early cases they serve quite well; available precedents allowed attacks on stigmatization by labeling without procedural safeguards, mass exclusion from schools, and employment decisions based on unsupported assumptions. Orthodox due-process and equal-protection analysis led to important gains. But as the official actions have replaced presumptions with determinations, as expertise replaces $a$ priori assumptions, and especially as the issue of barriers comes to the fore, the old rules do not work. Scrutiny of classification and rationality alike seem to demand approval of official decisions. The transit cases

\footnotetext{
${ }^{67}$ For a similar criticism, see Ely, Democracy and Distrust, p. 150.
} 
do not appear at first glance to require even this much attention, for they seem not to involve legal discrimination at all.

That the standard rules do not permit the desired conclusions is not, of course, sufficient reason for abandoning them if they are sound. But the thrust of this book indicates that the traditional approaches are not good enough, that they distort history and language and rest on philosophical underpinnings diametrically opposed to those accepted by the framers of the equal-protection clause. Viewed in this light, the fact that the doctrines are inadequate for yet another disadvantaged group encourages still more rethinking.

If my reformulation were adopted, how would constitutional doctrine change? First, we would have to decide who was affected by a challenged law, in what ways, and how great the affected interests were. The disabled people affected by the policies examined here are disadvantaged; they are a minority, though, at about 36 million, rather large as minorities go; and they have been stigmatized in the ways discussed in Chapter 6. The fact that the Rodriguez majority opinion, one of the bases of this formulation, speaks of groups "saddled with disabilities" makes writing somewhat awkward, but it illustrates some important features of this situation. There is no reason to discard this concern for the disadvantaged when we consider those whose disadvantage stems primarily from physical fact rather than public policy.

The disabilities of the handicapped are imposed by nature rather than law, but these limitations have been aggravated by what may be called second-order disabilities; architectural barriers are a good example. These artificial handicaps have thwarted the exercise of specified constitutional rights. So, however badly the disabled fit into the concept of suspect classification, policies restricting them seem to bear a heavy burden of justification, while policies benefiting them do not. Indeed, equal treatment for the disabled may well require, not just permit, favored treatment: not so much reverse discrimination as extra money, extra schooling, extra attention.

It is the third part of Justice Marshall's constitutional test-the character of the state interest involved-that imposes some limitation on this protection. As I have suggested, there are times when safety demands that people with certain disabilities be excluded from certain tasks. The state interest here is great, but it should be yielded to only after the person is given a chance to demonstrate ability.

The interests that militate against barrier removal and aggressive rehabilitation seem to be primarily budgetary. As I have pointed out, the budgeting has not usually been very sophisticated. But even if the long-run costs of these programs exceed the costs of neglect, I do not 


\section{Equality under the Constitution}

think that eventuality would negate my argument. For we will never be able to weigh the costs until we begin to assume them. And once the barriers are removed, the disabled activists who emerge may well make us think about these costs in different ways.

The Constitution recognizes broad, lavish rights of education, habilitation, accessibility, and employment opportunity. Since the I970s federal laws have explicitly granted some of those rights. Will these laws render obsolete any discussion of the constitutional rights of the disabled? The Supreme Court's construction of three laws does not indicate that obsolescence is at hand. Each of these laws has a wideopen legislative history and invites various conflicting interpretations. Each decision has construed the law narrowly, reversing lower courts to weaken the law. And each case reveals a poor understanding of the scope and sources of congressional power.

\section{The New Judicial Activism}

In 1979, Southeastern Community College v. Davis ended a licensed practical nurse's efforts to get a registered nurse's training. Frances Davis had a severe hearing loss. Although she could lipread, used a hearing aid, and could hear nonverbal sounds, she had a marked difficulty in understanding speech. An LPN since 1967, she had fulfilled all requirements preparatory to clinical work in the associate degree nursing program of Southeastern Community College in North Carolina in 1973 and 1974 . But the college rejected her application to the program on the basis of an audiologist's report and the opinion of the director of the state's Board of Nursing that she would threaten the safety of patients in her care.

Davis sued under Section 504. The district court upheld the college, pointing out that in many nursing situations, such as, obviously, the operating room, surgical masks are worn, and therefore lipreading is impossible. ${ }^{68}$ By the time the case reached the Court of Appeals, it was I 978 and Joseph Califano, secretary of health, education, and welfare (HEW), had signed the regulations implementing Section 504. The appellate court interpreted these regulations to demand a ruling in Davis' favor. The decision relied on the definition of an "otherwise qualified handicapped individual" as one who "meets the requisite academic and technical standards"; the latter are defined as "all nonacademic admissions criteria that are essential to participation in the

${ }^{68}$ Davis v. Southeastern Community College, 424 F. Supp. I34I (E.D.N.C. I 976 ). 
program in question." ${ }^{69}$ Although it was true that Davis could not function where she could not lipread, there appeared to be a number of nursing situations in which she could perform adequately. "Thus, we hold the district court erred by considering the nature of the plaintiff's handicap in order to determine whether or not she was 'otherwise qualified' for admittance into the nursing program ... rather than by focusing upon her academic and technical qualifications as required by the newly promulgated regulations." ${ }^{70}$ If she met those standards, the college might have to modify the program to suit her abilities.

The Supreme Court would have none of this. Unanimously, it upheld the college and the district court. In an interpretation exactly contrary to that of the Court of Appeals, Justice Powell wrote:

Section 504 by its terms does not compel educational institutions to disregard the disabilities of handicapped individuals or to make substantial modifications in their programs to allow disabled persons to participate. Instead, it requires only that an "otherwise qualified handicapped individual" not be excluded from participation in a federally funded program "solely by reason of his handicap," indicating only that mere possession of a handicap is not a permissible ground for assuming an inability to function in a particular context....

The uncontroverted testimony of several members of Southeastern's staff and faculty established that the purpose of its program was to train persons who could serve the nursing profession in all customary ways. This type of purpose, far from reflecting any animus against handicapped individuals, is shared by many if not most of the institutions that train persons to render professional service. It is undisputed that respondent could not participate in Southeastern's nursing program unless the standards were substantially lowered. Section 504 imposes no requirement upon an educational institution to lower or to effect substantial modifications of standards to accommodate a handicapped person. ${ }^{71}$

If that interpretation were true, of course, it would effectively keep blind and deaf applicants out of medical school, and possibly out of other professional or graduate programs as well. After all, texts are not published in Braille, nor are lectures signed; would requiring these modifications exceed the law's mandate? The Court has a point here, however. Either of these two readings of the regulations is supportable. It is just not clear what "all nonacademic criteria" means. The legislative history is not much help either, because the Rehabilitation

\footnotetext{
${ }^{69} 45$ C.F.R. 84.3 (1977).

${ }^{70}$ Davis v. Southeastern Community College, 574 F.2d I I 58, I I6 I (4th Circ. I978).

${ }^{71} 99$ S. Ct. 2361, 2366-7, 2370-71. Emphasis supplied.
} 


\section{Equality under the Constitution}

Act was passed with little opposition or substantive discussion. ${ }^{72}$ And a deaf nurse does seem to present problems that a blind lawyer, for example, does not. Even though the safety argument is hard to swallow, since hospitals frequently risk patients' safety at the hands of students, interns, and residents, it is hard to envision the nurse doing her job effectively.

But what about a blind doctor? In 1972 David Hartman became the first blind medical student in recent American history. Though several schools had rejected him, Temple University-which, incidentally, is Gurmankin's alma mater-decided to admit him. The medical school's assistant dean described it as an "experiment" and said that both Hartman and the school would have to compromise. Recording for the Blind taped more than two dozen basic medical texts for Hartman. The experiment worked; he graduated in 1976 and now practices psychiatry. ${ }^{73}$

He did not have to sue to get into medical school, or to stay in. If he had done so-assuming that he waited until the law was passed and the regulations were signed-he almost certainly would have lost, if Davis is any guide. But the school was willing both to take a chance on him and to make adaptations as they became necessary. The lesson of this experiment is that no one knew whether a blind person could get through medical school until one was permitted to try. Blind medical students, like women marathon runners, could not prove they could do what there were good reasons for thinking them incapable of doing until the experts let them experiment. Likewise, we will never know whether a deaf person can become a nurse until a similar experiment is made. Theories, expert opinions, and audiologists' reports will not settle the issue.

This is the crucial point. If Section 504 is to have much force, its scope cannot be limited to situations in which handicapped people have already performed the job in question, and therefore animus or ignorance is the only possible explanation for rejection. (And it is far from obvious that generalizations about abilities are uncontaminated by prejudice; the experience of women, blacks, Jews, and numerous other groups suggests otherwise.) Some experimentation, some disregard of expert predictions, will be necessary. The Supreme Court erred in allowing preconceptions to dictate exclusion.

\footnotetext{
${ }^{72}$ See Congressional Record, I I 9: 5860-590I (February 28, 1973); 7102-38 (March 8, 1973); 16665-78 (May 28, 1973).

${ }^{73}$ New York Times, May 31, 1972, p. 37; September 10, 1972, p. 34; May 28, 1976, I, p. I4. Hartman's efforts to get into medical school were the subject of a fictionalized television film, Journey from Darkness, first aired in 1975.
} 
Two years later, Pennhurst State School and Hospital v. Halderman did to the Developmental Disabilities Act of 1975 what Davis had done to the Rehabilitation Act of $1973 .^{74}$ Pennhurst involved a confusing mixture of claims, federal and state, constitutional and statutory. The hospital that has been the focus of all this attention is an institution for the retarded in Spring City, Pennsylvania. When the case began, Pennhurst had about I, 200 residents, about half of whom were committed by their families and half by the courts. The residents' average age was thirty-six; the average stay was twenty-one years. Almost three-fourths of the residents were profoundly retarded.

Terri Lee Halderman was admitted in 1966, when she was twelve. In her eleven years at Pennhurst, she lost several teeth and broke her jaw, fingers, and a toe-no one seemed to know how-and her general condition deteriorated. She had a five-word vocabulary when she entered the hospital for training and treatment; by the time her parents removed her, she did not speak at all.

Her experience was typical for residents. The hospital was so badly understaffed that there were not enough personnel to provide therapy, training, or even safety. "The environment at Pennhurst is not only not conducive to learning new skills, but it is so poor that it contributes to losing skills already learned." In theory, adult patients who were not civilly committed were free to leave, but about half the units were locked-and to speak of someone like Terri as being "free" to leave is obvious nonsense.

The Haldermans filed a suit in federal district court which was certified as a class action on behalf of all persons who had been at Pennhurst since 1974 or might be sent there. The federal government was allowed to intervene as a plaintiff. Relying on both the Constitution and Section 504, the plaintiffs alleged that Pennhurst violated its residents' rights to habilitation and treatment.

Judge Raymond Broderick agreed. His findings of fact, which all parties accepted as correct, recounted the dangerous, unhealthy, and repressive conditions of Pennhurst, the neglect of patients, the inadequate training programs, and the physical and mental decline of many residents. He relied on Wyatt, Donaldson, and the Eighth and Fourteenth Amendments to conclude, "Once admitted to a state facility, the residents have a constitutional right to be provided with minimally adequate habilitation under the least restrictive conditions consistent with the purpose of the commitment," and "the Equal Protection Clause ... prohibits the segregation of the retarded in an isolated institution

${ }^{74}$ IOI S.Ct. I 53 I (198I). 
such as Pennhurst where the habilitation provided the retarded does not meet minimally adequate standards." He also ruled that Section 504 established a statutory right to "non-discriminatory habilitation."

Broderick's order enjoined any further acts of abuse by staff, the use of seclusion, restraint, or medication as punishment or for convenience, and the administering of excessive medication. He ordered Pennhurst to keep all buildings clean, odorless, and insect-free, and to develop an individualized program plan for each resident. All of these requirements were well within the letter and spirit of Wyatt and Donaldson, but the order went even further. Broderick forbade all further admissions to Pennhurst, and ordered that the hospital eventually be closed. He set no deadline, but he did appoint a "special master" to carry out the order and to arrange for the habilitation of all patients in the least restrictive community setting possible. ${ }^{75}$ The Court of Appeals held that the Developmental Disabilities and Bill of Rights Act "grants to the mentally retarded a right to treatment and habilitation," but reversed the part of Judge Broderick's order which required the eventual closing of Pennhurst and prohibited new admissions. ${ }^{76}$

The Supreme Court ruled in favor of the hospital. Writing for the majority, Justice Rehnquist denied that the law created any substantive rights for the developmentally disabled, made federal funding contingent on granting rights, or even necessarily applied to Pennhurst at all. The Court remanded the question of the existence of a private right of action under Section 6010, the respondents' claims under Section 504, and the constitutional questions.

Rehnquist's opinion emphasized the act's legislative history. He first addressed the Haldermans' argument that the law was a valid exercise of Congress' Fourteenth Amendment enforcement powers. Whether or not Congress had this power, Rehnquist argued, the real question was whether it had chosen to exercise it here. "We should not quickly attribute to Congress an unstated intent to act under its authority under the Fourteenth Amendment"-although the Court had not been inhibited from doing so in Fullilove v. Klutznick the year before. In previous cases where the Court had upheld laws under these enforcement powers, the purpose had been expressly stated. The legislative history of Section 6oro showed no such purpose. Furthermore, "The case for inferring intent is at its weakest where, as here, the rights asserted impose affirmative obligations on the States to fund certain

\footnotetext{
${ }^{75}$ Halderman v. Pennhurst State School and Hospital, 446 F. Supp. I 295, I $302-12$, I 319, I 323, I 326-29 (1977).

${ }^{76}$ Halderman v. Pennhurst State School and Hospital, 6I2 F. 2d 84, 97, I I 2-I6 (3d Circ. 1979).
} 
services, since we may assume that Congress will not implicitly attempt to impose massive financial obligations on the States." 77

Rehnquist then turned to the spending power, the basis of the federal government's case. He had no difficulty accepting either the notion that this was the power the Ninety-fourth Congress thought it was using or that idea "that Congress may fix the terms on which it will disburse federal money to the States." The question here, however, was "whether Congress ... imposed an obligation on the States to spend state money to fund certain rights as a condition of receiving federal moneys under the Act or whether it spoke merely in precatory terms." The opinion chose the latter interpretation. The act was not a bill of rights but "a mere federal-state funding statute"; the references to rights were "scattered" and "incidental." 78

As the Court saw this case, it had little to do with the disabled and much to do with legislative intent and federalism. The majority implicitly conceded that both the spending power and the Fourteenth Amendment give Congress the power to do what the plaintiffs argue the act has done. But the justices balked at concluding that Congress really intended to secure rights for the developmentally disabled or to exert so much control over the states. Every possible presumption is entertained in favor of congressional circumspection and state autonomy.

Board of Education v. Rowley continued the trend. ${ }^{79}$ The issue was whether 94-I 42's requirement of a "free appropriate public education" gave ten-year-old Amy Rowley the right to have a sign-language interpreter assigned to her in school. Amy, like her parents, was deaf, but she had some residual hearing. Her parents had trained her in "total communication," a method that includes mouthing words, lipreading, signing, touching, and hearing aids. When Amy reached school age, her parents had met with school administrators in Westchester County, New York, as the federal law requires, to develop an individual education plan for her.

They decided to place Amy in a regular kindergarten class at Furnace Woods School in Peekskill. She got a hearing aid and, briefly, an interpreter, but he reported that he was not needed. In the first grade, Amy was also given a tutor and speech therapy. The school denied the Rowleys' persistent requests for an interpreter. The parents took their

\footnotetext{
7 Pennhurst State School and Hospital v. Halderman, Ior S.Ct. I 531 , I $538-45$, 1539. Emphasis in the original. The previous cases cited included Katzenbach v. Morgan, 384 U.S. 64 I (1966); Oregon v. Mitchell, 400 U.S. I 2 (1970). Cf. Slaughter-House Cases, 83, U.S. 36 (1872); Plessy v. Ferguson, 163 U.S. 537 (1 896).

${ }^{78}$ IOI S.Ct. I 53 I, I $539-40$.

${ }^{79} 50$ U.S.L.W. 4925 (1982).
} 
case to a hearing examiner, to the New York State Commissioner for Education, and finally to the federal courts. Meanwhile, Amy stayed with her class at Furnace Woods. Although she understood only about 60 percent of what was said in class, her class performance was above average. ${ }^{80}$

The district court ruled in Amy's favor. The judge's treatment of the case was sensitive and humane. Amy was getting an adequate education, he ruled, but that did not mean that she was learning as much as she would were she not deaf. Perhaps, he surmised, she could do better, both academically and socially, if less of her energy were channeled into compensating for her handicap.

An "appropriate education" could mean an "adequate education"-that is, an education substantial enough to facilitate a child's progress from one grade to another and to enable him or her to earn a high school diploma. An "appropriate education" could also mean one which enables the handicapped child to achieve his or her full potential. Between these two extremes, however, is a standard which I conclude is more in keeping with the regulations and with the Equal Protection decisions which motivated the passage of the Act, and with common sense. This standard would require that each handicapped child be given an opportunity to achieve his or her full potential commensurate with the opportunity provided to other children. ${ }^{81}$

Again the Supreme Court chose state power over federal, narrow construction over broad. For the majority, Rehnquist wrote, "Noticeably absent from the language of the statute is any substantive standard prescribing the level of education to be accorded handicapped children." Rehnquist found support in the legislative history for a minimal construction of 94-I42; he stressed Congress' concern in 1975 for children denied any education. "We conclude that the "basic floor of opportunity' provided by the Act consists of access to specialized instruction and related services which are individually designed to provide educational benefit to the handicapped child.” Amy's success indicated that she had received the required benefits. Justice Blackmun chided the lower courts for their lack of respect for the state officials' judgment. ${ }^{82}$

Rowley, like Pennhurst, reflects a view of federal-state relations that

${ }^{80}$ Rowley v. Board of Education, 483 F. Supp. 528, 530-32 (S.D.N.Y. 1980); affirmed, 632 F. 2d 947 (2d Circ. 1980).

${ }^{81} 483$ F. Supp. $528,534-36$.

${ }^{82} 50$ U.S.L.W. 4925, 4929, 4932, 4934-35. The interior quote is from H.R. no. 94332 , p. 14. 
has ominous overtones. With little guidance from statutory language or legislative history, the Court prefers constructions that give wide discretion to the states. This new brand of judicial activism seems to ignore what one had thought was the established principle of federal supremacy.

None of these opinions suggests that Congress lacks the power to regulate the states' treatment of the disabled. Rehnquist concedes in Pennhurst that the spending power and the Fourteenth Amendment gave Congress all it needed. The spending power also suffices with respect to $94-142$ and Section 504 of the Rehabilitation Act. What has troubled the Court is an uncertainty about how much of its power Congress intended to use in enacting these laws, an uncertainty that neither language nor history allays. Pennhurst has an incredulous tone reminiscent of Slaughter-House and Plessy. Surely Congress would let us know if it meant to use its Fourteenth Amendment powers; surely Congress should not be presumed to require the states actually to spend money; surely Congress would say so unambiguously if it meant to enact a bill of rights for the disabled. The Court presumes similar congressional timidity in Davis and Rowley. But nothing in the Constitution, the laws, or any other authority dictates such timidity.

There is no reason to presume that Congress will always label a law as an exercise of a particular power. Nor is there reason to presume, in general, that Congress will hesitate to direct the states, or, in particular, that Congress will hesitate to use the Fourteenth Amendment to direct the states. Therefore, in construing this kind of law, the Court has no reason to give maximum autonomy to the states and to attribute minimum initiative to Congress. Indeed, since the Constitution explicitly grants broad powers to the national government and leaves to the states what is left over, there is good reason to prefer the opposite kind of interpretation.

In each of these cases, there are good reasons to read the laws as upholding the claims of the disabled parties. In Davis, a broad reading of Section 504 was necessary to allow the disabled to compete for jobs; in Pennhurst, a broad reading of the Developmental Disabilities Act was necessary to end warehousing; in Rowley, a broad reading of 94-I42 was necessary to allow a schoolchild to become a full participant in classroom activity. In each case, the Supreme Court needlessly weakened a law that was a legitimate exercise of congressional power.

Indeed, the power to help the disabled goes beyond what Congress has claimed and the Court has conceded. The education and employment laws need not have rested on the spending power, and need not 
have been limited to programs that receive federal funds. Section 5 of the Fourteenth Amendment grants Congress more power than it has exercised.

Such an interpretation of Section 5 follows from my broad interpretation of Section I, but would be compatible with narrower readings. One could reasonably conclude that Section 5 gives Congress more power than Section I gives the courts. Although Justice Rehnquist has argued that the courts should limit the application of the equalprotection clause to "classifications based on race or on national origin, the first cousin of race," this position does not compel the conclusion that Congress should so limit Section $5 .^{83}$ But it would be difficult to justify interpreting Section 5 more narrowly than Section $\mathrm{I}$.

I have argued for a generous interpretation of the Fourteenth Amendment, an interpretation that recognizes many rights for the disabled. Acceptance of Congress' power under Section 5 does not require such an interpretation. But if the Constitution allows the courts to accept the claims to habilitation, accessibility, and employment opportunity, then the Constitution allows Congress to legislate to secure those claims. A broad construction of congressional power follows from a broad construction of individual rights. The Rehabilitation Act of 1973 and the Education Act of 1975 are "appropriate legislation" within the scope of Section 5 of the Fourteenth Amendment.

And these laws do not exhaust that power. The Constitution grants ample legislative and judicial powers to help disabled people become full citizens. If legislative inaction and judicial action instead help keep the disabled in the attic, it will be because government has chosen to do so.

\footnotetext{
${ }^{83}$ Trimble v. Gordon, 430 U.S. 762, 777 (1977).
} 